\title{
Evaluation of skeletal muscle regeneration in experimental model after malnutrition
}

\author{
A. Pertille ${ }^{a}$, K. F. Moura ${ }^{a}$, C. Y. Matsumura ${ }^{b}$, R. Ferretti ${ }^{b}$, D. M. Ramos ${ }^{a}$, \\ A. C. Petrini ${ }^{a}$, P. C. Oliveira ${ }^{a}$ and C. A. Silva ${ }^{a}$ \\ ${ }^{\text {a}}$ Laboratory of Neuromuscular Plasticity, Graduate Program in Science of Human Movement, Universidade Metodista de \\ Piracicaba - UNIMEP, Rodovia do Açúcar, 7000, CEP 13400-911, Piracicaba, SP, Brazil \\ ${ }^{b}$ Department of Anatomy, Biosciences Institute of Botucatu, Universidade Estadual Paulista - UNESP, \\ Distrito de Rubião Júnior, s/n, CEP 18618-970, Botucatu, SP, Brazil \\ *e-mail: apertille@unimep.br
}

Received: July 10, 2015 - Accepted: September 20, 2015 - Distributed: February 28, 2017

(With 4 figures)

\begin{abstract}
The aim of this study was to analyze muscle regeneration after cryoinjury in the tibialis anterior muscle of young rats that were malnourished and then recovered. Forty Wistar rats were divided into a nourished group that received a normal protein diet (14\% casein) for 90 days and a malnourished and recovered rats group (MR) that was submitted to 45 days of malnutrition with a hypoproteic diet ( $6 \%$ casein) followed by 45 days of a normal protein diet ( $14 \%$ casein). After the recovery period, all of the animals underwent cryoinjury in the right tibialis anterior muscle and euthanasia after 7, 14 and 21 days. The amount of connective tissue and the inflammation area was higher in the malnutrition recovered injury MR group (MRI) at 14 days post-injury $(\mathrm{p}<0.05)$. Additionally, the cross-sectional area (CSA) of the regenerated fibers was decreased in the MRI $(\mathrm{p}<0.05)$. The MyoD and myogenin protein levels were higher in the nourished injury group. Similar levels of TGF- $\beta 1$ were found between groups. The proposed malnutrition protocol was effective in showing delayed changes in the regeneration process of the tibialis anterior muscle of young rats. Furthermore, we observed a delay in muscle repair even after nutritional recovery.
\end{abstract}

Keywords: skeletal muscle, protein malnutrition, cryolesion, myogenic regulatory factors, muscle healing process.

\section{Avaliação da regeneração do músculo esquelético em modelo experimental após desnutrição}

\section{Resumo}

O objetivo do presente estudo foi analisar a regeneração muscular após criolesão no músculo tibial anterior de ratos jovens desnutridos e recuperados. Foram utilizados 40 ratos da linhagem Wistar, divididos em 2 grupos: ratos nutridos receberam dieta normoproteica (14\% de caseína) por 90 dias; e ratos desnutridos e recuperado submetidos a duas fases nutricionais pós-desmame, correspondendo a 45 dias de desnutrição com dieta hipoproteica (6\% caseína), seguida por 45 dias de dieta normoproteica (14\% caseína). Ao completar a fase de recuperação, todos os animais foram submetidos à criolesão no músculo tibial anterior direito e a eutanasia ocorreu 7, 14 e 21 dias após a lesão. A quantidade de tecido conjuntivo e a área de inflamação 14 dias pós-lesão foi maior no grupo desnutrido, recuperado e lesado (MRI - malnourished, recovered and injured group) $(\mathrm{p}<0,05)$. A área de secção transversa (AST) das fibras regeneradas do grupo MRI foi menor $(\mathrm{p}<0,05)$. O conteúdo das proteínas MyoD e Miogenina foi maior no grupo nutridos e lesados. A citocina TGF- $\beta 1$ não apresentou diferença entre os grupos. O protocolo proposto foi eficaz para demonstrar alterações no processo de regeneração do músculo tibial anterior de ratos jovens, atrasando o reparo muscular mesmo após a recuperação nutricional.

Palavras-chave: músculo esquelético, desnutrição proteica, criolesão, fatores de regulação miogênica, processo de recuperação do músculo.

\section{Introduction}

Undernutrition is a pathological condition of nutritional imbalance due to insufficient intake of calories, protein, vitamins, minerals and/or other nutrients. The number of undernourished people in the world is extremely high and reached almost 1 billion in 2010 (FAO, 2010). Malnutrition in developing countries has mostly been attributed to a low 
protein diet (Ihemelandu, 1985; Ge and Chang, 2001) or a low quality of food consumed (Morgane et al., 2002).

A lack of protein intake affects growth, differentiation and regeneration of cells because of interference in the immune function, protein synthesis and collagen breakdown (Silveira et al., 1997). In children, protein-malnutrition slows physical growth and metabolic development, which persists even after a return to healthy nutritional status (Ihemelandu, 1985; Díaz-Cintra et al., 2007; Hernandez et al., 2008; Miñana-Solis and Escobar, 2008).

The structural and functional properties of skeletal muscles can be adapted according to environmental conditions by changing the amount and type of proteins (Michael, 2000; Baldwin and Haddad, 2002; Capitanio et al., 2006). Furthermore, skeletal muscles have the extraordinary capacity for regeneration after injury (Lopes-Martins et al., 2006). The muscle regeneration process occurs in four stages: degeneration, inflammation, remodeling and regeneration (Crisco et al., 1994). Degeneration is present within the first few hours after injury, and it is characterized by myofilaments and sarcolemma disruption, cell necrosis and hematoma formation followed by the inflammatory response (Sverzut and Chimelli, 1999; Tidball, 2005; Järvinen et al., 2005). In the inflammatory stage, neutrophils phagocytize cellular debris and macrophages remove dead tissue and stimulate the production of cytokines that activate satellite cells in the injury site (Fielding et al., 1993; Belcastro et al., 1996; Järvinen et al., 2000; Kannus et al., 2003). This activation leads to the expression of myogenic lineage markers such as myogenic differentiation (MyoD) and myogenin. MyoD regulates the early stage of regeneration with the activation and proliferation of satellite cells. Myogenin is required for the fusion of myogenic precursor cells to new or previously existing fibers during process differentiation and maturation of myoblasts. (Füchtbauer and Westphal, 1992; Rantanen et al., 1995; Creuzet et al., 1998; Järvinen et al., 2000). During the remodeling phase, restoration of the functional capacity of the injured muscle occurs by maturation and organization of the extracellular matrix (Tidball, 1995; Järvinen et al., 2000; Kannus et al., 2003;
Goetsch et al., 2003). The repair and remodeling phases generally overlap. After 21 days of injury, the damaged muscle is almost totally regenerated.

The success of muscle repair depends on the nature and the extension of injury. However, in all cases, the process involves the four stages of regeneration. External factors, such as physical therapy, accelerate the regeneration process and leads to the rapid return of function (Carlson and Faulkner, 1989; Järvinen et al., 2000; Ferrari et al., 2005). In addition, muscle regeneration depends on nutrients for activation of the immune system and muscle fiber synthesis. Undernutrition impairs the proliferation of satellite cells resulting in muscle atrophy and myonuclei decrease (Carlson and Faulkner, 1988; Dedkov et al., 2001). Because skeletal muscle regeneration can be influenced by undernutrition, we examined the effect of a low-protein diet followed by nutritional recovery on the regeneration process after cryoinjury in the tibialis anterior muscle of young rats.

\section{Material and Methods}

\subsection{Animals}

Forty young Wistar rats (obtained from the rat breeding colony of the Faculdade de Ciências da Saúde (FACIS-UNIMEP)) were housed under controlled temperature conditions with a 12/12-h light/dark cycle and permitted free access to food and water. All of the experiments were performed in accordance with the guidelines of the use of animals set forth by our institution.

\subsection{Experimental groups}

The newly weaned animals (21 days old) were randomly divided into two groups: the nourished group $(\mathrm{N}, \mathrm{n}=20)$ was given only a normal protein $\operatorname{diet}(14 \%$ casein; AIN 93M - PragSoluções Serviços e Comércio Ltda) for 90 days, and the Malnutrition Recovery group (MR, $\mathrm{n}=20$ ) was given a low protein diet ( $6 \%$ casein; AIN PragSoluções Serviços e Comércio Ltda) for 45 days and recovery for another 45 days with a normal protein ration (Table 1).

Table 1. Composition of experimental diets.

\begin{tabular}{lcc}
\hline \multicolumn{1}{c}{ Ingredients } & $\begin{array}{c}\text { Normal-protein diet AIN 93M (g) } \\
(\mathbf{1 4 \%} \text { protein) }\end{array}$ & $\begin{array}{c}\text { Low-protein diet AIN 6 (g) } \\
\text { (6\% protein) }\end{array}$ \\
\hline Corn starch & 465.7 & 508.0 \\
Casein & $\mathbf{1 4 0 . 0}$ & $\mathbf{6 6 . 0}$ \\
Dextrin & 155.0 & 166.5 \\
Saccharose & 100.0 & 121.0 \\
Soybean oil & 40.0 & 40.0 \\
Fiber (microcellulose) & 50.0 & 50.0 \\
L-Cysteine & 1.8 & 1.0 \\
Choline chorine & 2.5 & 2.5 \\
Mineral mix G & 35.0 & 35.0 \\
Vitamin mix & 10.0 & 10.0 \\
TOTAL & $\mathbf{1 0 0 0 . 0}$ & $\mathbf{1 0 0 0 . 0}$ \\
\hline
\end{tabular}


At 111 days, all of the animals were submitted to muscle cryoinjury in the right tibialis anterior (TA) muscle to evaluate the potential of regeneration in normal or under malnutrition conditions. Thus, the groups were defined as Nourished Injury (NI) and Malnutrition Recovery Injury (MRI). The groups were used for morphological analysis 14 days after injury ( $\mathrm{n}=5$ for the group) and for molecular analysis at 7, 14 and 21 days after injury $(n=15$ for the group). The left TA was used for the control.

\subsection{Monitoring of body weight and food intake}

The control feed intake box was analyzed weekly by calculating the proportional feed intake per animal and body weight of each rat using a digital balance (GEHAKA, BG 1000). For the data analysis, the two most important stages of work were selected (66 days, which is the end of the malnutrition protocol and 111 days, which is the end of the recovery phase).

\subsection{Cryoinjury}

The animals were anesthetized by intraperitoneal injection of ketamine hydrochloride $(1.16 \mathrm{~g} / 10 \mathrm{~mL})$ and Xylazine $(2 \mathrm{~g} / 100 \mathrm{~mL})$ at a 3:2 ratio and at a dose of $0.09 \mathrm{~mL} / 100 \mathrm{~g}$ body weight. After showing signs of anesthesia, the right TA was exposed, and a metal bar of $1 \mathrm{~cm} / 0.5 \mathrm{~cm}$ cooled in liquid nitrogen $\left(-196^{\circ} \mathrm{C}\right)$ for 30 seconds was pressed in the muscle belly for 10 seconds. The cryoinjury was repeated two times according the Miyabara et al. (2006) protocol. Later, the muscle fascia and skin were sutured.

\subsection{Cryosection and analysis}

Cryostat transverse-sections $(8 \mu \mathrm{m})$ of the right and left TA were stained with hematoxylin-eosin (HE) or Masson's trichrome. Using a light microscope (Olympus, Optical Co. Ltd, Tokyo, Japan) and Pro-Plus ${ }^{\mathrm{TM}} 6.2$ Image software (Media Cybernetics), two random sections from each animal were analyzed quantitatively through a $4 \mathrm{X}$ and $20 \mathrm{X}$ objective. In the analysis of the inflammation/regeneration area, we measured the area of muscle in the stages of inflammation and regeneration, which were characterized by intense inflammatory infiltrate and the presence of fibers in regeneration. The results were obtained by calculating the proportion of this area with the section of the entire muscle. Another performed analysis was the quantification of the cross-sectional area (CSA) of the fibers to verify their regeneration maturation. Muscle fibers that had a centralized nucleus were indicative of regeneration (right tibialis muscle) and were measured and compared with normal fibers (left tibialis muscle). During this analysis, 400 fibers in the phase of regeneration and 200 normal fibers were measured per animal (Pertille et al., 2012).

The connective tissue sections stained with Masson's trichrome were quantified with images acquired through a 20X objective, and 12 images were analyzed, which were chosen randomly. The images were superimposed and contained a 210 intersection grid, which accounted for the connective tissue, and then the result was transformed into a percentage.

\subsection{Western blotting}

The transformation levels of growth factor-beta (TGF- $\beta$ ), MyoD and Myogenin were quantified using Western blots from the Nourished injury group (NI, n=15) and malnutrition recovery injury group (MRI, $\mathrm{n}=15$ ) at 7, 14 and 21 days. Western blots were performed as previously described (Taniguti et al., 2011). Briefly, the muscles were lysed in assay lysis buffer ( $1 \%$ Triton, $10 \mathrm{mM}$ sodium pyrophosphate, $100 \mathrm{mM} \mathrm{NaF}, 10 \mathrm{~g} / \mathrm{ml}$ aprotinin, $1 \mathrm{mM}$ PMSF and $0.25 \mathrm{mM} \mathrm{Na} 3 \mathrm{VO}$ ). The samples were centrifuged at $12,581 \times \mathrm{g}$ for $20 \mathrm{~min}$, and the soluble fraction was re-suspended in Laemmli loading buffer ( $2 \%$ SDS, $20 \%$ glycerol, $0.04 \mathrm{mg} / \mathrm{ml}$ bromophenol blue, $0.12 \mathrm{M}$ Tris $\cdot \mathrm{HCl}, \mathrm{pH} 6.8$ and $0.28 \mathrm{M}$-mercaptoethanol). An aliquot $(30 \mu \mathrm{g})$ of the total protein homogenate from NI and MRI was loaded onto $12 \%$ SDS polyacrylamide gels. The proteins were transferred to a nitrocellulose membrane (electrotransfer apparatus from Bio-Rad Laboratories, Hercules, CA). The membranes were then blocked with 3\% skim milk-Tris $\cdot \mathrm{HCl}$-buffered saline Tween buffer (TBST; $10 \mathrm{mM}$ Tris $\cdot \mathrm{HCl}, \mathrm{pH} 8$, $150 \mathrm{mM} \mathrm{NaCl}$ and $0.05 \%$ Tween 20 ) and incubated with the primary antibodies overnight at $4{ }^{\circ} \mathrm{C}$, washed in TBST, incubated with peroxidase-conjugated secondary antibodies and developed using the SuperSignal West Pico Chemiluminescent Substrate kit (Pierce Biotechnology, Rockford, IL). To control for Western blot transfer and non-specific changes in protein levels, the blots were stripped and re-probed with glyceraldehyde-3-phosphate dehydrogenase (GAPDH). The luminescent signal was captured (G: Box iChemi camera, Syngene, Cambridge, UK), and the band intensities were quantified using the analysis software that was provided by the manufacturer (Gene Tools Version 4.01, Syngene, Cambridge, UK). The following primary antibodies were used for Western blotting: 1) TGF- $\beta$ (mouse monoclonal; Sigma-Aldrich, St Louis, Missouri, USA); 2) MyoD (rabbit polyclonal M-318; sc-760, Santa Cruz Biotechnology); 3) Myogenin (mouse monoclonal, Sigma, M5815) and 4) GAPDH (rabbit polyclonal; Santa Cruz Biotechnology, Santa Cruz, CA). The corresponding secondary antibody used for Western blotting was an appropriate peroxidase-labeled affinity-purified IgG antibody (H+L) (KPL, Gaithersburg, $\mathrm{MD})$. The bands were captured in the G-box system (GeneSys), saved as an image and quantification of the densitometry was performed using Image $J^{\circledR}$. The data are expressed as arbitrary units obtained by the studied protein values divided by the GAPDH.

\subsection{Statistical analysis}

All of the data are expressed as the means \pm standard deviation (SD). The statistical analysis for direct comparison between the means of the two groups was performed using Student's $t$-test, and a one way ANOVA was used for multiple statistical comparisons between groups, followed by a Tukey-Kramer. A value of $\mathrm{p}<0.05$ was considered statistically significant. 


\section{Results}

At the end of the malnutrition period (66-day-old rats), the body weight of the MR group was $67.8 \%$ lower than the $\mathrm{N}$ group $(\mathrm{p}<0.05)$. After the recovery period with the introduction of a normal protein diet (111-day-old rats), the body mass was similar in the two groups (Table 2). The food intake was lower in the MR group (at 66 days old) during the malnutrition period compared with the $\mathrm{N}$ group $(\mathrm{p}<0.05)$. In the recovery period, the consumption of a normal protein diet was similar between the groups (Table 2).

After 14 days of muscle injury, the inflammation / regeneration area was twice the size in the MRI compared with NI $(p<0.05)$ group. Additionally, the percentage of connective tissue was higher in the MRI group $(p<0.05)$ (Figures 1 and 2).

To evaluate CSA, the fibers were analyzed in the post-injury healing process (fibers with central nuclei, right tibialis muscle) and the normal fibers (with peripheral nuclei, left tibialis muscle). In the MRI group 14 days after injury, the CSA of regenerated fibers decreased $26 \%$ compared with normal fibers in the same group $(\mathrm{p}<0.05)$. In the NI group, post-injury regenerated fibers showed no statistical difference compared with the normal fibers (Figure 3). Additionally, the CSA in fibers with peripheral and central nuclei was smaller in the MRI group compared with the NI group $(\mathrm{p}<0.05)$ (Figure 3).

At seven days after the injury, MyoD protein levels were higher in the NI group compared with the MRI group
(Figures 4A, B). The myogenin levels were $45.2 \%$ higher in the NI group $(\mathrm{p}<0.05) 14$ days after the injury compared with the NI muscles 21 days after the injury. Conversely, in the MRI group, there was no difference in the periods studied (Figures 4A, D). The levels of TGF- $\beta 1$ were similar between the NI and the MRI groups. Seven days after the injury, higher levels of TGF- $\beta 1$ were shown in both groups $(p<0.05)$ compared with the periods 14 and 21 days after the injury (Figures $4 \mathrm{~A}, \mathrm{C}$ ).

\section{Discussion}

The malnutrition and nutritional recovery protocol proposed in this study showed muscle changes resulting from the protein restriction period. The MRI animals showed higher inflammation and connective tissue area 14 days after injury, which resulted in an impaired muscle regeneration process with decreased CSA, MyoD and myogenin protein levels.

Feed restriction significantly affects the growth and differentiation of cells, and the earlier the malnutrition, the greater the impairment in tissues and organs (Ihemelandu, 1985). Studies in rats, dogs and monkeys showed that protein restriction during pregnancy affects body weight and the number of muscle fibers of offspring (Nascimento et al., 1990; Oliveira et al., 1999; Nunes et al., 2002). In this study, animals began the period of malnutrition at 21 days of life, and after 45 days, they showed reduced food intake and body weight compared with the nourished group.

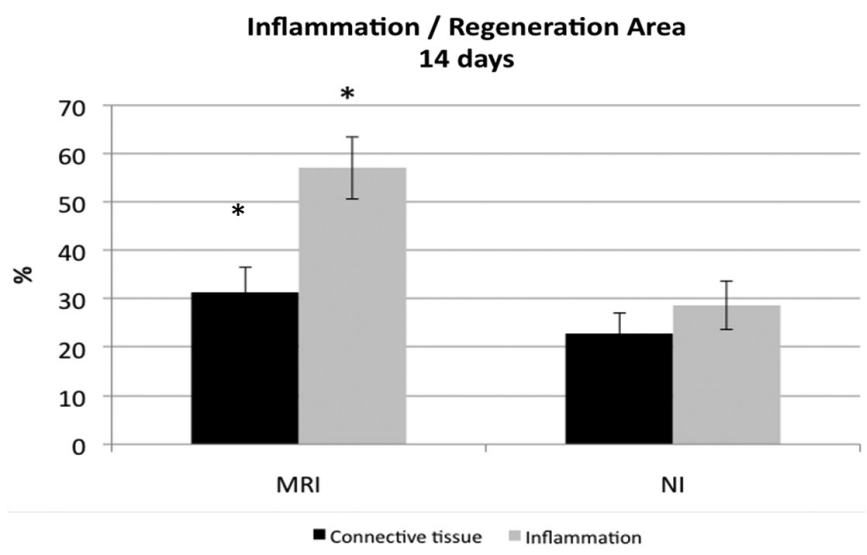

Figure 1. The percentage of connective tissue and inflammation area in the malnutrition recovery injured group (MRI) and normally nourished injured group (NI). *Differs from the respective NI group, $p<0.05$.

Table 2. Body weight and food intake per day in 66 and 111-day-old rats.

\begin{tabular}{lcccc}
\hline & $\begin{array}{c}\text { Malnutrition } \\
\text { recovery group (MR) } \\
\text { 66 days old }\end{array}$ & $\begin{array}{c}\text { Malnutrition } \\
\text { recovery group (MR) } \\
\text { 111 days old }\end{array}$ & $\begin{array}{c}\text { Normally nourished } \\
\text { group (N) } \\
\text { 66 days old }\end{array}$ & $\begin{array}{c}\text { Normally nourished } \\
\text { group (N) } \\
\text { 111 days old }\end{array}$ \\
\hline Body weight (g) & $74.2 \pm 13.1$ & $279.9 \pm 18.1$ & $230.2 \pm 15.3^{*}$ & $348.2 \pm 25.4$ \\
Food intake/day & $6.36 \pm 0.9$ & $28.84 \pm 3.7$ & $16.4 \pm 2.7^{*}$ & $25.7 \pm 6.7$ \\
(g) & & & & \\
\hline
\end{tabular}

*Significantly different from the malnutrition recovery group (MR) at 66 days old $(\mathrm{p}<0.05)$. 

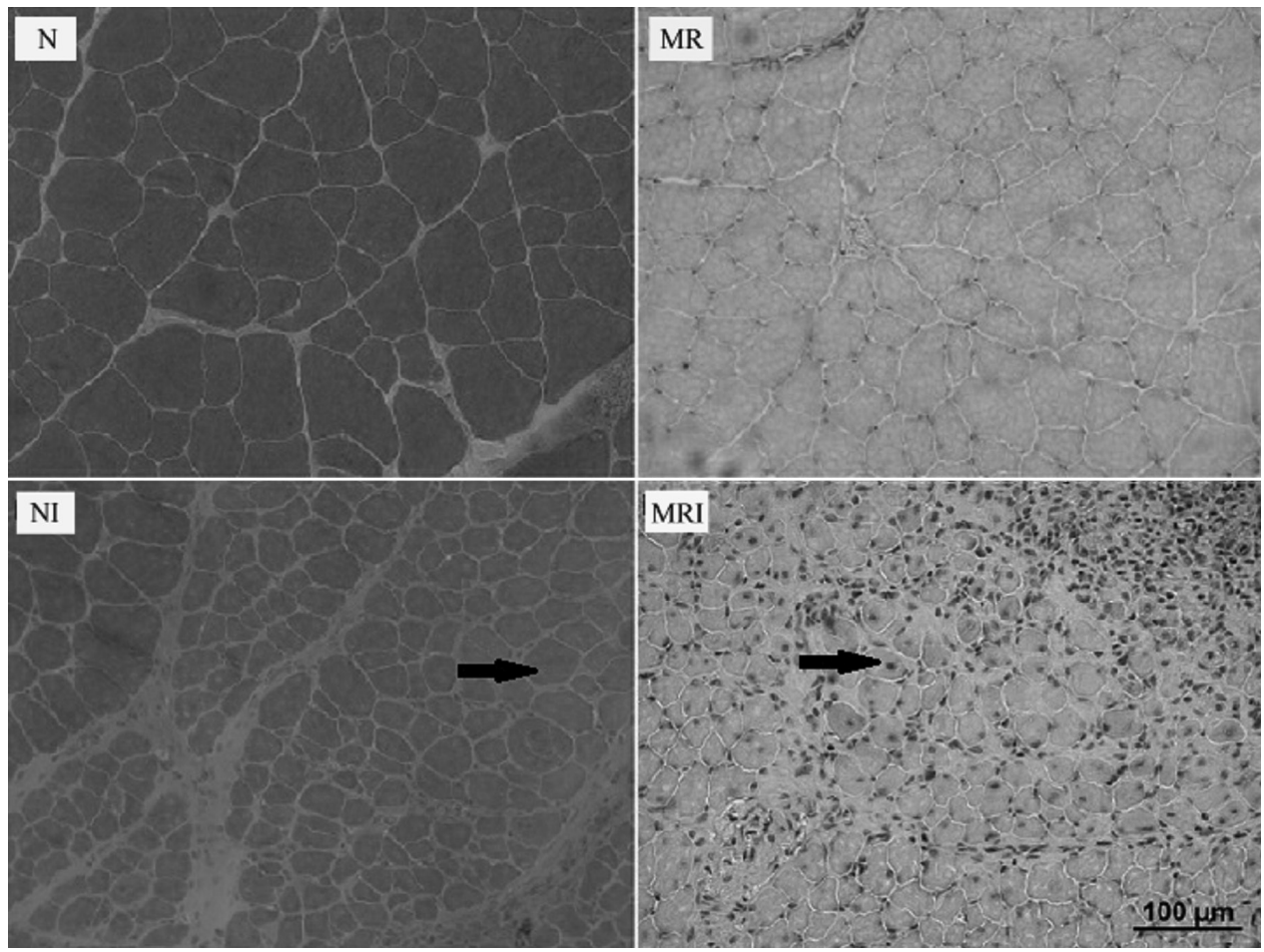

Figure 2. Cross sections of the tibialis anterior muscle stained with HE. Normally nourished group (N): control fibers; Normally nourished injured group (NI): fibers in regeneration process; Malnutrition recovery group (MR): control fibers; Malnutrition recovery injured group (MRI): fibers in the regeneration process. The arrows indicate the position of the central nuclei. Bar $=100$ micron.

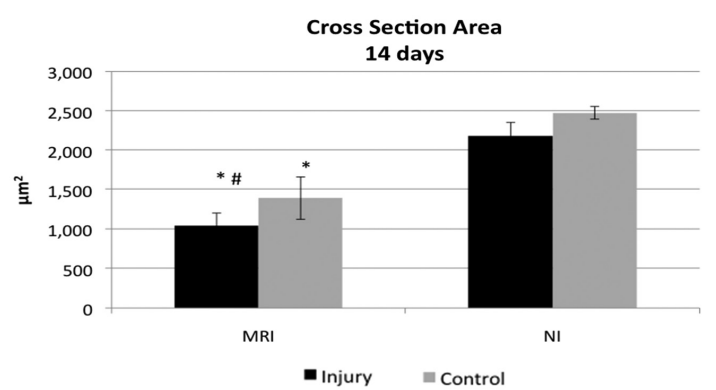

Figure 3. Cross-sectional area (CSA) of muscular fibers in the malnutrition recovery injured (MRI) and normally nourished injured (NI) groups. Injury: CSA of fibers with central nuclei (right tibialis muscle); Control: CSA of fibers with peripheral nuclei (left tibialis muscle). *Differs from the respective NI group, $\mathrm{p}<0.05$; \#Differs from control MRI, $\mathrm{p}<0.05$.

Escriva et al. (1991) observed the body weight gain reduction associated with functional alterations in insulin action in tissues in young rats subjected to protein restriction for four weeks. Latorraca et al. (1998) evaluated the offspring of rats undernourished during pregnancy and breastfeeding. The animals exposed to a low protein diet had a reduction in insulin secretion, probably as a consequence of deficient $\mathrm{Ca}^{2+}$ absorption in pancreatic cells. Anselmo et al. (2009) evaluated rats subjected to a multi-deficient diet during pregnancy and observed a reduction in insulin levels and cortisol compared with the control group (18\% casein).

After the recovery period (45 days), the MR group had similar food intake and body weight compared with the $\mathrm{N}$ group. However, the histological analysis showed that the CSA of left tibialis anterior fibers (control) was $44 \%$ lower than the nourished group, indicating that food restriction affects the development of skeletal muscle. The decrease in the number and diameter of fibers in malnourished young animals occurs due to the loss of myofibril and consequently loss of fibers. Myotube needs protein to synthetize actin and myosin after the fusion of myoblasts during growth (Ihemelandu, 1985).

Bedi et al. (1982) evaluated malnutrition by CSA, type and total number of muscle fibers in extensor digitorum longus (EDL) and soleus muscles of rats. The animals were subjected to malnutrition during pregnancy and lactation or after weaning. All of the animals were then permitted to nutritionally recover for a long period. The results indicated that malnutrition during the early stages affect body mass, which causes weight reduction and CSA muscle decrease, even after 5 months of recovery to a normal diet. However, malnourished post-weaning rats followed with a normal diet for seven months showed muscle recovery. In our study, tibialis anterior muscles of malnourished post-weaning rats were analyzed after two 


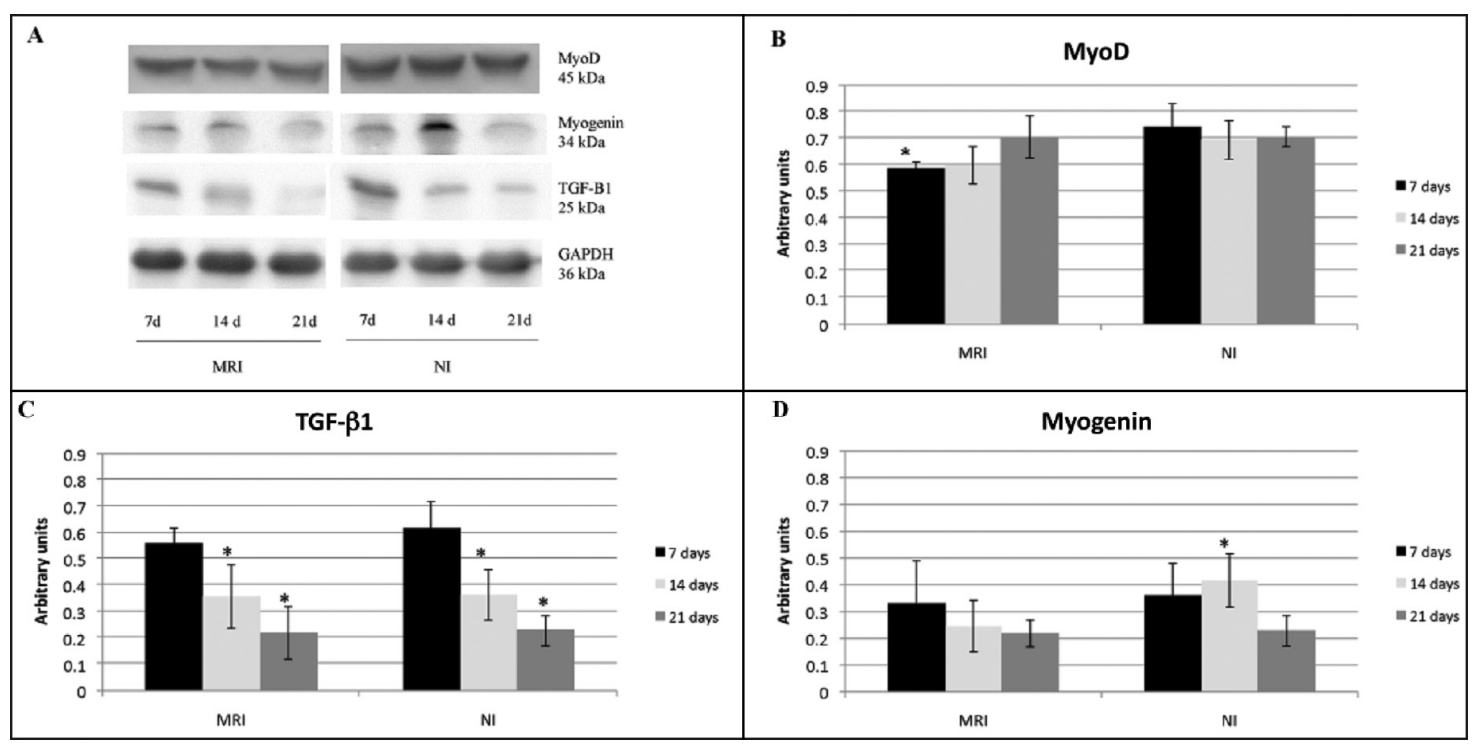

Figure 4. Western blotting of MyoD, Myogenin, TGF- $\beta 1$ and GAPDH in the malnutrition recovery injured (MRI) and normally nourished injured (NI) groups at 7, 14 and 21 days after cryoinjury. (A) Immunoreactive bands; (B) MyoD levels, *Differs from NI7 group, $\mathrm{p}<0.05$; (C) TGF- $\beta 1$ levels, *Differs from the respective group 7 days after injury, $\mathrm{p}<0.05$; (D) Myogenin levels, *Differs from NI21, $\mathrm{p}<0.05$.

months of nutritional recovery, but a reduction in muscle mass was still demonstrated.

Yamaguchi et al. (1993) showed that dietary restriction also reduced muscle weight and CSA in rats from 5 to 11 weeks old but did not interfere in the type of muscle fibers. Ruiz-Rosado et al. (2013) evaluated the type fiber in the EDL by histoenzymatic techniques and noted the possible adaptation of muscle fibers in adult rats that underwent chronic food restriction. The EDL muscle of undernourished young rats (15-45 days) showed a predominance of oxidative fibers, but when the rats reached adulthood (130-365 days), the proportion of the fiber type of control animal fibers (normal feed) and the malnourished rats was similar. These results indicate that the body tries to offset the changes caused by chronic food restriction in the long term.

To evaluate the muscle regeneration process in malnourished and recovered rats, all of the animals were subjected to cryoinjury. Considering that at 14 days after injury the muscle presents an advanced regeneration process with reduced inflammation and tissue connective area (Järvinen et al., 2005), our histological analysis was performed at this time. A study in two month old mice subjected to protein-energy malnutrition ( $4 \%$ protein diet) concluded that the nutritional status affects macrophage activation and the body's ability to establish an immune response (Fock et al., 2007). However, Barreto et al. (2012) showed that intrauterine malnutrition causes changes in the inflammatory response progress of offspring. In the malnourished group, the paw edema volume, C-reactive protein serum, albumin serum and cytokine levels were lower in the acute inflammation phase.
After the inflammatory phase, skeletal muscle regeneration consists of myofiber regeneration and connective tissue production. These two processes are simultaneous and competitive because excessive production of connective tissue completely inhibits muscle regeneration (Lehto et al., 1986). In this study, the inflammation / regeneration area was twice the MRI group, and there was also an increase in connective tissue compared with the NI group. These results indicate that the MRI group showed a delay in muscle regeneration because the inflammatory phase was longer.

TGF- $\beta 1$ is an important cytokine for the synthesis of the extracellular matrix and remodeling and is used to investigate the formation of fibrosis (Heldin et al., 1997). The aim of the study was to determine whether the malnourished animals would present a tendency to form fibrosis during the muscle regeneration process. The TGF- $\beta 1$ level was similar in all groups, and the level increased 7 days after injury. In the NI group, TGF- $\beta 1$ reduction at 14 and 21 days after injury was associated with a decrease in connective tissue found by the histological analysis. However, the TGF- $\beta 1$ reduction in the MRI group at 14 and 21 days, and the increase in connective tissue found by the histological analysis, cannot be used to conclude whether there is a tendency in the formation of fibrosis.

Another indication of the delay in muscle regeneration is reduction of CSA in regenerated fibers of the MRI group, which reached $74 \%$ of the normal muscle fibers (left TA). The NI group showed similar CSA fibers compared with normal fibers at 14 days post-injury.

The initial phase of activation and proliferation of satellite cells is characterized by MyoD expression, which increases at the initial stage of the regeneration process and 
reaches its maximum three days after injury (Tidball and Villalta, 2010). In this study, the samples were collected at 7, 14 and 21 days after injury and the MyoD levels were increased 7 days after injury in the NI compared with the MRI group.

Myogenin is expressed in advanced phases of regeneration. Myogenin is a satellite cell differentiation marker for the repair or formation of myoblasts. In young animals, the myogenin level started to increase at the third day after injury, reached its peak at the seventh day, and then returned to normal levels (Srikuea et al., 2010; Corbu et al., 2010). However, these data were not similar to the findings in the present study; myogenin levels increased in the NI14 compared with the NI21 group, which indicated that 14 days after injury, the fibers were in a more advanced regeneration phase in the NI compared with the MRI group. In the MRI group, the myogenin level was similar in all of the periods.

The reduction of MyoD and myogenin levels, the reduction of CSA muscle fibers, and the increase of inflammation and connective tissue area in the MRI group suggest that the muscle regeneration process occurred slower in post-weaning malnourished individuals followed by nutritional recovery than in animals fed normally. Nutritional recovery over the long term (for 5 or 7 months) reveals different data compared with the results found in this study because intrauterine malnutrition generates higher damage than post-weaning malnutrition.

To gain a better understanding of the malnutrition consequences in muscles, other experiments should be performed in offspring of malnourished rats and recovered animals over an extended period. Other techniques to characterize the histological and molecular dysfunction of muscle should be used such as muscle CSA, the total number of muscle fibers and inflammation markers such as TNF- $\alpha$.

\section{Conclusion}

The proposed protocol of post-weaning malnutrition followed by nutritional recovery was effective in causing changes in the muscle regeneration process of young rats. A delay was observed in muscle repair with increased inflammation and connective tissue and reduced muscle fiber cross-sectional area and MyoD and myogenin levels. TGF- $\beta 1$ levels did not change with dietary protein restriction.

\section{References}

ANSELMO, C.W.S.F., PEREIRA, P.B., CATANHO, M.T. and MEDEIROS, M.C., 2009. Effects of the Electromagnetic field, $60 \mathrm{~Hz}, 3 \mu \mathrm{T}$, on the hormonal and metabolic regulation of undernourished pregnant rats. Brazilian Journal of Biology $=$ Revista Brasileira de Biologia, vol. 69, no. 2, pp. 397-404. http:// dx.doi.org/10.1590/S1519-69842009000200024. PMid:19675945.

BALDWIN, K.M. and HADDAD, F., 2002. Skeletal Muscle Plasticity: Cellular and molecular responses to altered physical activity paradigms. American Journal of Physical Medicine \&
Rehabilitation, vol. 81, no. 11, suppl., pp. 40-51. http://dx.doi. org/10.1097/00002060-200211001-00006. PMid:12409810.

BARRETO, R.R., FRANCO, E.S., BRASILEIRO, C.F., OLIVEIRA, A.P., DIMECH, G.S., MALTA, D.J.N., CAZUZU, J.S.I., LEITE, A.C.R., SILVA, T.G. and MAIA, M.B.S., 2012. Early undernutrition is associated with attenuated inflammatory response and alteration in pharmacological efficacy of indomethacin in rats. European Journal of Pharmaceutical Sciences, vol. 46, no. 1-2, pp. 56-63. http://dx.doi.org/10.1016/j.ejps.2012.02.005. PMid:22366113.

BEDI, K.S., BIRZGALIS, A.R., MAHON, M., SMART, J.L. and WAREHAM, A.C., 1982. Early life undernutrition in rats. 1. Quantitative histology of skeletal muscles from underfed young and refed adult animals. British Journal of Nutrition, vol. 47, no. 3, pp. 417-431. http://dx.doi.org/10.1079/BJN19820053. PMid:7082615.

BELCASTRO, A.N., ARTHUR, G.D., ALBISSER, T.A. and RAJ, D.A., 1996. Heart, liver, and skeletal muscle myeloperoxidase activity during exercise. Journal of Applied Physiology, vol. 80, no. 4, pp. 1331-1335. PMid:8926263.

CAPITANIO, M., CANEPARI, M., CACCIAFESTA, P., LOMBARDI, V., CICCHI, R., MAFFEI, M., PAVONE, F.S. and BOTTINELLI, R., 2006. Two independent mechanical events in the interaction cycle of skeletal muscle myosin with actin. The National Academy of Sciences of the USA, vol. 103, no. 1, pp. 8792. http://dx.doi.org/10.1073/pnas.0506830102. PMid:16371472.

CARLSON, B.M. and FAULKNER, J.A., 1988. Reinnervation of long-term denervated muscle freely grafted into an innervated limb. Experimental Neurology, vol. 102, no. 1, pp. 50-56. http:// dx.doi.org/10.1016/0014-4886(88)90077-5. PMid:3181352.

CARLSON, B.M. and FAULKNER, J.A., 1989. Muscle transplantation between young and old rats: age of host determines recovery. The American Journal of Physiology, vol. 256, no. 6 Pt 1, pp. C1262-C1266. PMid:2735398.

CORBU, A., SCARAMOZZA, A., BADIALI-DEGIORGI, L., TARANTINO, L., PAPA, V., RINALDI, R., D'ALESSANDRO, R., ZAVATTA, M., LAUS, M., LATTANZI, G. and CENACCHI, G., 2010. Satellite cell characterization from aging human muscle. Neurological Research, vol. 32, no. 1, pp. 63-72. http://dx.doi. org/10.1179/174313209X385725. PMid:20092696.

CREUZET, S., LESCAUDRON, L., LI, Z. and FONTAINEPERUS, J., 1998. MyoD, myogenin, and desmin-nls-lacZ transgene emphasize the distinct patterns of satellite cell activation in growth and regeneration. Experimental Cell Research, vol. 243, no. 2, pp. 241-253. http://dx.doi.org/10.1006/excr.1998.4100. PMid:9743584.

CRISCO, J.J., JOKL, P., HEINEN, G.T., CONNELL, M.D. and PANJABI, M.M., 1994. A muscle contusion injury model. Biomechanics, physiology, and histology. The American Journal of Sports Medicine, vol. 22, no. 5, pp. 702-710. http://dx.doi. org/10.1177/036354659402200521. PMid:7810797.

DEDKOV, E.I., KOSTROMINOVA, T.Y., BORISOV, A.B. and CARLSON, B.M., 2001. Reparative myogenesis in long-term denervated skeletal muscles of adult rats results in a reduction of the satellite cell population. The Anatomical Record, vol. 263, no. 2, pp. 139-154. http://dx.doi.org/10.1002/ar.1087. PMid:11360231.

DÍAZ-CINTRA, S., GONZÁLEZ-MACIEL, A., MORALES, M.A., AGUILAR, A., CINTRA, L. and PRADO-ALCALÁ, R.A., 2007. Protein malnutrition differentially alters the number of glutamic acid decarboxylase-67 interneurons in dentate gyrus and CA1-3 subfields of the dorsal hippocampus. Experimental 
Neurology, vol. 208, no. 1, pp. 47-53. http://dx.doi.org/10.1016/j. expneurol.2007.07.003. PMid:17706195.

ESCRIVA, F., KERGOAT, M., BAILBE, D., PASCUAL-LEONE, A.M. and PORTHA, B., 1991. Increased insulin action in the rat after protein malnutrition early in life. Diabetologia, vol. 34, no. 8, pp. 559-564. http://dx.doi.org/10.1007/BF00400273. PMid:1936658.

FERRARI, R.J., PICCHI, L.D., BOTELHO, A.P. and MINAMOTO, V., 2005 [viewed 1 July 2014]. Processo de regeneração na lesão muscular: uma revisão. Fisioterapia em Movimento [online], vol. 18, no. 2, pp. 63-71. Available from: http://www.researchgate. net/publication/266318935

FIELDING, R.A., MANFREDI, T.J., DING, W., FIATARONE, M.A., EVANS, W.J. and CANNON, J.G., 1993. Acute phase response in exercise. III. Neutrophil and IL-1b accumulation in skeletal muscle. American Journal of Physiology. Regulatory, Integrative and Comparative Physiology, vol. 265, no. 1 Pt 2, pp. R166-R172. PMid:8342683.

FOCK, R.A., VINOLO, M.A., DE MOURA SÁ ROCHA, V., DE SÁ ROCHA, L.C. and BORELLI, P., 2007. Protein-energy malnutrition decreases the expression of TLR-4/MD-2 and CD14 receptors in peritoneal macrophages and reduces the synthesis of the TNF-alpha in response to lipopolysaccharide (LPS) in mice. Cytokine, vol. 40, no. 2, pp. 105-114. http://dx.doi.org/10.1016/j. cyto.2007.08.007. PMid:17950615.

FOOD AND AGRICULTURE ORGANIZATION OF THE UNITED NATIONS - FAO, 2010 [viewed 1 July 2014]. Global hunger declining, but still unacceptably high International hunger targets difficult to reach [online]. Rome: FAO. Available from: http://www.fao.org/docrep/012/al390e/al390e00.pdf

FÜCHTBAUER, E.M. and WESTPHAL, H., 1992. MyoD and Myogenin are coexpressed in regenerating skeletal muscle of the mouse. Developmental Dynamics, vol. 193, no. 1, pp. 3439. http://dx.doi.org/10.1002/aja.1001930106. PMid:1311614.

GE, K.Y. and CHANG, S.Y., 2001. Definition and measurement of child malnutrition. Biomedical and Environmental Sciences, vol. 14, no. 4, pp. 283-291. PMid:11862608.

GOETSCH, S.C., HAWKE, T.J., GALLARDO, T.D., RICHARDSON, J.A. and GARRY, D.J., 2003. Transcriptional profiling and regulation of the extracellular matrix during muscle regeneration. Physiological Genomics, vol. 14, no. 3, pp. 261-271. http://dx.doi. org/10.1152/physiolgenomics.00056.2003. PMid:12799472.

HELDIN, C.H., MIYAZONO, K. and DIJKE, P., 1997. TGF- $\beta$ sinalling from cell membrane to nucleu sthrough SMAD proteins. Nature, vol. 390, no. 6659, pp. 465-471. http://dx.doi. org/10.1038/37284. PMid:9393997.

HERNÁNDEZ, A., BURGOS, H., MONDACA, M., BARRA, R., NÚÑEZ, H., PÉREZ, H., SOTO-MOYANO, R., SIERRALTA, W., FERNÁNDEZ, V., OLIVARES, R. and VALLADARES, L., 2008. Effect of prenatal protein malnutrition on long-term potenciation and BDNF protein expression in the rat entorhinal córtex after neocortical and hippocampal tetanization. Neural Plasticity, vol. 2008, pp. 1-9. http://dx.doi.org/10.1155/2008/646919. PMid: 18604298

IHEMELANDU, E.C., 1985. Fibre number and sizes of mouse soleus muscle in early postnatal protein malnutrition. Acta Anatomica, vol. 121, no. 2, pp. 89-93. http://dx.doi.org/10.1159/000145949. PMid:3976346.
JÄRVINEN, T.A., KAARIAINEN, M., JÄRVINEN, M. and KALIMO, H., 2000. Muscle strain injuries. Current Opinion in Rheumatology, vol. 12, no. 2, pp. 155-161. http://dx.doi. org/10.1097/00002281-200003000-00010. PMid:10751019.

JÄRVINEN, T.A.H., JÄRVINEN, T.L.N., KÄÄRIÄINEN, M., KALIMO, H. and JÄRVINEN, M., 2005. Muscle injuries: biology and treatment. The American Journal of Sports Medicine, vol. 33, no. 5, pp. 745-764. http://dx.doi.org/10.1177/0363546505274714. PMid:15851777.

KANNUS, P., PARKKARI, J., JARVINEN, T.L., JARVINEN, T.A. and JARVINEN, M., 2003. Basic science and clinical studies coincide: active treatment approach is needed after a sports injury. Scandinavian Journal of Medicine \& Science in Sports, vol. 13 , no. 3 , pp. 150-154. http://dx.doi.org/10.1034/j.16000838.2003.02225.x. PMid:12753486.

LATORRACA, M.Q., REIS, M.A.B., CARNEIRO, E.M., MELLO, M.A.R., VELLOSO, L.A., SAAD, M.J. and BOSCHERO, A.C., 1998. Protein deficiency and nutritional recovery modulate insulin secretion and the early steps of insulin action in rats. The Journal of Nutrition, vol. 128, no. 10, pp. 1643-1649. PMid:9772130.

LEHTO, M., JARVINEN, M. and NELIMARKKA, O., 1986. Scar formation after skeletal muscle injury, a histological and autoradiographical study in rats. Archives of Orthopaedic and Traumatic Surgery, vol. 104, no. 6, pp. 366-370. http://dx.doi. org/10.1007/BF00454432. PMid:3964044.

LOPES-MARTINS, R.A., MARCOS, R.L., LEONARDO, P.S., PRIANTI JUNIOR, A.C., MUSCARÁ, M.N., AIMBIRE, F., FRIGO, L., IVERSEN, V.V. and BJORDAL, J.M., 2006. Effect of low-level laser (Ga-Al-As $655 \mathrm{~nm}$ ) on skeletal muscle fatigue induced by electrical stimulation in rats. Journal of Applied Physiology, vol. 101, no. 1, pp. 283-288. http://dx.doi.org/10.1152/ japplphysiol.01318.2005. PMid:16627677.

MICHAEL, K., 2000. Relationship of Skeletal Muscle Atrophy to Functional Status: A Systematic Research Review. Biological Research for Nursing, vol. 2, no. 2, pp. 117-131. http://dx.doi. org/10.1177/109980040000200205. PMid:11337817.

MIÑANA-SOLIS, M.D. and ESCOBAR, C., 2008. Post-weaning protein malnutrition in the rat produces short and long term impairment, in contrast to earlier and later periods. International Journal of Biological Sciences, vol. 4, no. 6, pp. 422-432. http:// dx.doi.org/10.7150/ijbs.4.422. PMid:19043606.

MIYABARA, E.H., MARTIN, J.L., GRIFFIN, T.M., MORISCOT, A.S. and MESTRIL, R., 2006. Overexpression of inducible $70 \mathrm{kDa}$ heat shock protein in mouse attenuates skeletal muscle damage induced by cryolesioning. American Journal of Physiology. Cell Physiology, vol. 290, no. 4, pp. C1128-C1138. http://dx.doi. org/10.1152/ajpcell.00399.2005. PMid:16291818.

MORGANE, P.J., MOKLER, D.J. and GALLER, J.R., 2002. Effects of prenatal protein malnutrition on the hippocampal formation. Neuroscience and Biobehavioral Reviews, vol. 26, no. 4, pp. 471-483. http://dx.doi.org/10.1016/S0149-7634(02)00012-X. PMid:12204193.

NASCIMENTO, O.J.M., MADI, K., SILVA, J.B.G., SOARES FILHO, P.J., HAHN, M.D., COUTO, B. and FREITAS, M.R.G., 1990. Considerações sobre o músculo estriado na desnutrição protéica estudo experimental, em ratos albinos. Arquivos de NeuroPsiquiatria, vol. 48, no. 4, pp. 395-402. http://dx.doi.org/10.1590/ S0004-282X1990000400001. PMid:2128795. 
NUNES, M.L., BATISTA, B.B., MICHELI, F. and BATISTELLA, V., 2002. Efeitos da desnutrição precoce e reabilitação nutricional em ratos. Jornal de Pediatria, vol. 78, no. 1, pp. 39-44. PMid:14647810.

OLIVEIRA, F.L., OLIVEIRA, A.S., SCHIMIDT, B. and AMÂNCIO, O.M., 1999. Desnutrição energética intra-uterina em ratos: alterações musculoesqueléticas na $1^{\mathrm{a}}$ e $2^{\mathrm{a}}$ gerações. Jornal de Pediatria, vol. 75, no. 5, pp. 350-356. http://dx.doi. org/10.2223/JPED.328. PMid:14685513.

PERTILlE, A., MACEDO, A.B. and OLIVEIRA, C.P., 2012. Evaluation of muscle regeneration in aged animals after treatment with low-level laser therapy. Revista Brasileira de Fisioterapia, vol. 16, no. 6, pp. 495-501. PMid:23060238.

RANTANEN, J., HURME, T., LUKKA, R., HEINO, J. and KALIMO, H., 1995. Satellite cell proliferation and the expression of myogenin and desmin in regenerating skeletal muscle: evidence for two different populations of satellite cells. Laboratory Investigation, vol. 72, no. 3, pp. 341-347. PMid:7898053.

RUIZ-ROSADO, A., FERNÁNDEZ-VALVERDE, F., MARISCALTOVAR, S., HINOJOSA-RODRIGUEZ, C.X., HERNÁNDEZVALENCIA, J.A., ANZUETO-RIOS, A., GUADARRAMA-OLMOS, J.C., SEGURA-ALEGRÍA, B. and JIMÉNEZ-ESTRADA, I., 2013. Histoenzymatic and Morphometric Analysis of Muscle Fiber Type Transformation during the Postnatal Development of the Chronically Food-Deprived Rat. The Journal of Histochemistry and Cytochemistry, vol. 61, no. 5, pp. 372-381. http://dx.doi. org/10.1369/0022155413480149. PMid:23392735.

SILVEIRA, I.S., RAISER, A.G., POLYDORO, A.S. and SANTOS, M.N., 1997. Efeitos da dieta na cicatrização de fratura distais de fêmur imobilizadas com pinos intramedulares em cão. Acta Cirurgica Brasileira, vol. 12, no. 3, pp. 178-181. http://dx.doi. org/10.1590/S0102-86501997000300008.
SRIKUEA, R., PHOLPRAMOOL, C., KITIYANANT, Y. and YIMLAMAI, T., 2010. Satellite cell activity in muscle regeneration after contusion in rats. Clinical and Experimental Pharmacology \& Physiology, vol. 37, no. 11, pp. 1078-1086. http://dx.doi. org/10.1111/j.1440-1681.2010.05439.x. PMid:20726992.

SVERZUT, A C. M. and CHIMELLI, L., 1999. O papel das células satélites nas respostas adaptativas do tecido muscular esqueléticos. Fisioterapia \& Pesquisa., vol. 6, no. 2, pp. 132-139. http://dx.doi.org/10.1590/fpusp.v6i2.79615.

TANIGUTI, A.P.T., PERTILle, A., MATSUMURA, C.Y., NETO, H.S. and MARQUES, M.J., 2011. Prevention of muscle fibrosis and myonecrosis in $\mathrm{mdx}$ mice by suramin, a TGF- $\beta 1$ blocker. Muscle \& Nerve, vol. 43, no. 1, pp. 82-87. http://dx.doi. org/10.1002/mus.21869. PMid:21108244.

TIDBALL, J.G., 1995. Inflammatory cell response to acute muscle injury. Medicine and Science in Sports and Exercise, vol. 27, no. 7, pp. 1022-1032. http://dx.doi.org/10.1249/00005768199507000-00011. PMid:7564969.

TIDBALL, J.G., 2005. Inflammatory processes in muscle injury and repair. Regulatory, Integrative and Comparative Physiology, vol. 288, no. 2, pp. R345-R353. http://dx.doi.org/10.1152/ ajpregu.00454.2004. PMid:15637171.

TIDBALL, J.G. and VILLALTA, S.A., 2010. Regulatory interations between muscle and the immune system during muscle regeneration. Regulatory, Integrative and Comparative Physiology, vol. 298, no. 5, pp. 1173-1187. http://dx.doi.org/10.1152/ajpregu.00735.2009. PMid:20219869.

YAMAGUCHI, A., HORIO, Y., SAKUMA, K. and KATSUTA, S., 1993. The effect of nutrition on the size and proportion of muscle fiber types during growth. Journal of Anatomy, vol. 182, no. 1, pp. 29-36. PMid:8509298. 